\title{
Hospitality And Tourism Industry Performance in Indonesia Based on Benjamin Graham's Perspective
}

\author{
Ima Kristina Yulita ${ }^{1}$ and Caecilia Wahyu Estining Rahayu ${ }^{2}$ \\ Economic Faculty, Sanata Dharma University, Yogyakarta, Indonesia ${ }^{1}$ \\ Economic Faculty, Sanata Dharma University, Yogyakarta, Indonesia ${ }^{2}$
}

\begin{abstract}
This research aims at determining the performance of hospitality and tourism industry in Indonesia based on the analysis of financial ratios using the Benjamin Graham's perspective. The total number of samples is 9 companies listed in Indonesia Stock Exchange in 2012-2016. The analysis of financial ratios includes Earning PerShare (EPS), Price to Earnings Ratio (PER), Price to Book Value (PBV), Return on Equity (ROE), Current Ratio (CR) and Debt to Equity Ratio (DER). First, this research examined the effects of those six financial ratios on stock prices either partially or simultaneously. Afterwards, only financial ratios that had a significant effect on stock prices are analyzed using Benjamin Graham. Hypothesis testing was conducted using Multiple Linear Regression analysis. The results point out that: (1) EPS, PER, PBV, ROE, CR and DER simultaneously affect the stock prices; (2) EPS, PER, PBV and DER partially affect the stock prices; (3) Seven companies that meet 2 of 4 determined criteria are ARTA, BAYU, JIHD, JSPT, KPIG, PDES and SHID. The results of this research are expected to provide recommendations for investors in selecting companies' shares with good performance based on 4 financial ratios.
\end{abstract}

Keywords. Hospitality and tourism industry, financial ratio, financial performance, stock prices, Benjamin Graham.

Abstrak. Penelitian ini bertujuan untuk mengetahui kinerja industri hotel dan pariwisata di Indonesia berdasarkan analisis rasio keuangan menggunakan perspektif Benjamin Graham. Jumlah sampel adalah 9 perusahaan yang terdaftar di Bursa Efek Indonesia pada tahun 2012-2016. Analisis rasio keuangan termasuk Earning Per-Share (EPS), Price to Earnings Ratio (PER), Price to Book Value (PBV), Return on Equity (ROE), Current Ratio (CR) dan Debt to Equity Ratio (DER) . Pertama, penelitian ini menguji pengaruh dari enam rasio keuangan terhadap harga saham baik secara parsial maupun secara simultan. Setelah itu, hanya rasio keuangan yang memiliki pengaruh signifikan terhadap harga saham yang dianalisis menggunakan Benjamin Graham. Pengujian hipotesis dilakukan menggunakan analisis Regresi Linier Berganda. Hasil menunjukkan bahwa: (1) EPS, PER, PBV, ROE, CR dan DER secara simultan mempengaruhi harga saham; (2) EPS, PER, PBV dan DER secara parsial mempengaruhi harga saham; (3) Tujuh perusahaan yang memenuhi 2 dari 4 kriteria yang ditentukan adalah ARTA, BAYU, JIHD, JSPT, KPIG, PDES dan SHID. Hasil penelitian ini diharapkan dapat memberikan rekomendasi bagi investor dalam memilih saham perusahaan dengan kinerja yang baik berdasarkan 4 rasio keuangan.

Kata kunci : industri hotel dan pariwisata, rasio keuangan, kinerja keuangan, harga saham, Benjamin Graham

Correspondence.yulitaimakristina@gmail.com, caecilia50@gmail.com

History of article. Received: Oktober 2018, Revision: Januari 2019, Published: Maret 2019

\section{INTRODUCTION}

Based on 2016 Performance Report of the Ministry of Tourism (www.kemenpar.go.id, 2018), Indonesia with the branding of Wonderful Indonesia has improved its position $\left(47^{\text {th }}\right)$, higher than Malaysia $\left(96^{\text {th }}\right)$ and Thailand $\left(83^{\text {rd }}\right)$, in the list. According to the Ministry of Tourism (www.kemenpar.go.id, 2017), the tourism sector has provided significant contribution to the improvement of Indonesia's foreign exchange income - from the $5^{\text {th }}$ position in 2011 and 2012 to the $4^{\text {th }}$ in 2013, 2014 and 2015, and to the $2^{\text {nd }}$ in 2016. In addition, the contribution of tourism sector to the national GDP of 2016 reached the number of Rp176-184 trillion and provided employment for 12 million people in 2016 (kemenpar.go.id, 2018). Consequently, these numbers encourages potential investors to make investment in the sector of tourism by investing in the capital market - buying shares of companies in the hospitality and tourism industries.

One of the approaches to stock investing is fundamental analysis. For potential investors, fundamental analysis is one of the ways to obtain insights on a company performance which is conducted by reviewing financial report published by the company (Subramanyam, 2014). According to Sudana (2015), determining the strengths and weaknesses of a company 
requires analysis on the financial statement, including evaluation on the performance record of the company's management and put it into consideration in the preparation of future plans in company level. Fundamental analysis is a mean to understand stock's performance as the by determining whether certain securities are "worth buying" or "worthy selling" based on analysis on financial statements (Samsul, 2015).

In conducting fundamental analysis, the implementation of financial ratios analysis includes several financial ratios, such as market value ratio, profitability ratio, liquidity ratio and solvency ratio (Subramanyam, 2014; Sudana, 2015; Frensidy, 2016). According to Tandelilin (2017), investors need to pay attention to EPS (Earning Per Share), PER (Price to Earnings Ratio) and PBV (Price to Book Value) of a company in their fundamental analysis since EPS, PER and PBV are employed in the estimation of the intrinsic value of shares. ROE (Return on Equity) determines the ability of a company to generate profit after taxes using company's capital (Sudana, 2015). Higher ROE indicates higher efficiency in the use of company's capital. Current Ratio (CR) is one of the liquidity ratios that measure the ability of a company in paying current debts using company's own assets (Sudana, 2015). Higher CR indicates better ability in paying short-term debt using company's own assets. Debt Equity Ratio (DER) is one of the solvency ratios that suggest the number of company operations supported with debt compared to the number of company operations supported with the company's own capital (Sari and Kennedy, 2017).

Many researches have been done on financial ratios testing on stock prices (as a proxy of a company's performance) in several companies listed on the Stock Exchange and come up with inconclusive findings (Esmeili, 2002; Hashemi and Behzadfar, 2011; Miri and Abrahimi, 2011; Kohansal et al., 2013). This research focuses on the performance of companies in hospitality and tourism industries and uses fundamental analysis with 6 financial ratios on the companies. This research examines the effects of six financial ratios on company's stock prices. In the next step, in order to understand the performance of the stocks, only financial ratios with significant effects on stock prices were analyzed using Benjamin Graham's criteria. This research is different from other researches with the similar topic since this research uses Benjamin Graham's perspective. Graham (2017) is a practitioner in the field of investment, and also the mentor of Warren Buffet (the richest person in the United States who is the most successful investor).

\section{RESEARCH FRAMEWORK \& HYPOTHESIS}

In their fundamental analysis, investors need to pay attention to EPS, PER and PBV of a company since EPS, PER and PBV are employed in the estimation of the intrinsic value of shares (Tandelilin, 2017). ROE indicates company's ability to generate profit after taxes using company's own capital (Sudana, 2015). Higher ROE indicates higher efficiency in the use of company's capital. CR is one of the liquidity ratios that measures company's ability in paying its current debt using company's current assets (Sudana, 2015). Larger CR indicates better ability in paying meet short-term debt using company's own current assets. DER is one of the solvency ratios that suggests the number of company's operations supported with debt compared to the number of company operations supported with the company's own capital (Sari and Kennedy, 2017).

The result of the research by Kohansal et al. (2013) shows that financial ratios, such as ROE, $\mathrm{CR}$, Financial Leverage and Asset Turnover, are significantly related to stock prices of the companies in food industry. Miri and Abrahimi's research (2011) shows that there is a significant relationship between financial ratios and stock prices. Hashemi and Behzadfar (2011) in their research find that EPS, working capital to assets, ROA (Return on Assets), net profit and sales turnover affect stock prices. According to Asri (2017), EPS and ROA have positive effects on stock prices, which mean that every increase in EPS and ROA raises the stock price. Andy (2016) finds that changes in PER and DY (dividend yield) correlates with stock prices, whether in short term or long term. Changes in DY have positive 
correlation with changes in stock prices, while changes in PER have negative correlation.

Artha et al. (2014) finds that Book Value per Share (BVS), PBV, DER, stock price trends, BI rate, world oil prices and Rupiah exchange rate had a significant effect on agricultural stock price. The result of the research by Prasetyo (2014) on 15 hospitality and tourism companies listed on Indonesia Stock Exchange (IDX) in 2010-2012 indicates that financial performance has significant effects on stock prices, and that there are variations in terms of stock prices for healthy and unhealthy companies. The result of the research by Sari and Kennedy (2017) shows that ROE has negative effects on stock prices, DER has negative effects on stock prices and PER has positive effects on stock prices but EVA does not have positive effects on stock prices.

Researches on financial performance have also been conducted in other countries. The research by Kohansal et al. (2013) shows that financial ratios, such as ROE, Current Ratio, Financial Leverage and Asset Turnover, are significantly related to stock prices of the companies in food industry in Iran. Miri and Abrahimi (2011) find that there is a significant relationship between financial ratios and stock prices in Iran. The research by Hashemi and Behzadfar (2011) finds that EPS, working capital to assets, ROA, net profit and sales turnover affect stock prices. Esmaeli (2002) finds that there is a significant correlation between financial ratios and stock prices. Based on above theory and researches, hypotheses are formulated as follows:

H1: EPS, PER, PBV, ROE, CR, and DER partially have significant effects on stock prices of the companies in hospitality and tourism sub-sectors.

H2: EPS, PER, PBV, ROE, CR, and DER simultaneously have significant effects on stock prices of the companies in hospitality and tourism sub-sectors.

\section{METHOD}

The population in this research is all companies in hospitality and tourism sub-sectors listed on Indonesia Stock Exchange in 2012-2016, which is 17 companies. The samples were chosen using purposive sampling method. The selected companies are 9 companies with positive record of profit, which is set as the criterion, during the research period. The following is the list of the selected 9 companies in hospitality and tourism sub-sectors that are the samples of this research.

Table 1. The List of The Companies in Hospitality and Tourism sub-sectors

\begin{tabular}{|c|c|c|}
\hline No & Code & Company \\
\hline 1 & ARTA & PT Artavest Tbk. \\
\hline 2 & BAYU & PT Bayu Buana Travel Service \\
\hline 3 & INPP & $\begin{array}{l}\text { PT Indonesian Paradise } \\
\text { Property Tbk }\end{array}$ \\
\hline 4 & ICON & $\begin{array}{l}\text { PT Island Concepts Indonesia } \\
\text { Tbk }\end{array}$ \\
\hline 5 & JIHD & $\begin{array}{l}\text { PT Jakarta Internasional Hotels } \\
\text { and Development Tbk }\end{array}$ \\
\hline 6 & JSPT & PT Setiabudi Internasional Tbk \\
\hline 7 & KPIG & PT MNC Land Tbk \\
\hline 8 & PDES & $\begin{array}{l}\text { PT Destinasi Tirta Nusantara } \\
\text { Tbk }\end{array}$ \\
\hline 9 & SHID & $\begin{array}{l}\text { PT Hotel Sahid } \\
\text { Internasional Tbk }\end{array}$ \\
\hline
\end{tabular}

Source: www.idx.co.id

The data used in this research are secondary data in the form of annual closing stock price data and annual financial statements in 2012-2016 (www.idx.co.id.). The dependent variable in this research is stock prices. Stock prices are measured at the closing price of each stock at the end of each year within the period of 2012-2016. The independent variables in this research are as follows:

Earning per Share (EPS). This ratio measures the net income per outstanding share. The formula is:

EPS $=\frac{\text { net profit }}{\text { the number of outstanding common shares }}$ According to Graham (2017), company with performance is the one with $>30 \%$ long-term EPS growth (previous 10 years), and has no negative EPS for the last 5 years.

Price to Earnings Ratio (PER). This ratio measures investors' assessment of the company's future prospects and is reflected in the share price that investors are willing to pay for profit earned by the company (Sudana, 2015). The formula is:

$$
\mathrm{PER}=\frac{\text { market price per share }}{\text { earnings per share }}
$$


According to Graham (2017), if PER is $<15$, the company's performance is good.

Price to Book Value (PBV). This ratio compares the value of the stock market with the book value of equity (Subramanyam, 2014). The formula is:

$$
\mathrm{PBV}=\frac{\text { equity market price per share }}{\text { book value of equity per share }}
$$

According to Graham (2017), a good company performs well when PBV is $<1.5$

Return on Equity (ROE). This ratio measures company's ability to generate profit after tax using company's own capital (Sudana, 2015). The formula is as follows:

$$
\mathrm{ROE}=\frac{\text { net profit }}{\text { common equity }}
$$

According to Graham (2017), if ROE is inclined toward stability or increases every year (assuming that average market capitalization > Rp175 billion), then the company's performance is categorized as good.

Current Ratio (CR). This ratio shows the availability of current assets in meeting current liabilities (Subramanyam, 2014).

The formula is : $\mathrm{CR}=\frac{\text { current assets }}{\text { current liabilities }}$ According to Graham (2017), a company performs well when $\mathrm{CR}$ is $>2$

Debt to Equity Ratio (DER). This ratio measures the percentage of funds granted by creditors to total equity (Subramanyam, 2014). The formula is as follows:

$$
\mathrm{DER}=\frac{\text { Total debt }}{\text { Total equity }}
$$

According to Graham (2017), if DER is $<1$, the company performs well.

\section{RESULT AND DISCUSSION}

\section{Multiple Linear Regression Analysis Test}

Multiple Linear Regression Analysis is employed to test the effects of 6 financial ratios on stock prices of the companies in hospitality and tourism sub-sectors. Multiple Linear regression model is eligible since it meets the criteria of classical assumption test, namely normality test, multicollinearity test, autocorrelation test and heteroscedasticity test (Ghozali, 2011). The following is the table of analysis results upon implementing Multiple Linear Regression Analysis:

\begin{tabular}{|c|c|c|c|c|c|c|}
\hline & \multirow[b]{2}{*}{ Model } & \multicolumn{2}{|c|}{$\begin{array}{c}\text { Unstandardized } \\
\text { Coefficients }\end{array}$} & \multirow{2}{*}{$\begin{array}{c}\text { Standardized } \\
\text { Coefficients } \\
\text { Beta } \\
\end{array}$} & \multirow[b]{2}{*}{$\mathrm{t}$} & \multirow[b]{2}{*}{ Sig. } \\
\hline & & B & Std. Error & & & \\
\hline 1 & (Constant) & -2180.027 & 502.630 & & -4.337 & .000 \\
\hline & LN_EPS & 530.645 & 62.231 & 1.773 & 8.527 & .000 \\
\hline & LN_PER & 463.366 & 61.509 & 1.422 & 7.533 & .000 \\
\hline & LN_PBV & 225.498 & 72.614 & .383 & 3.105 & .004 \\
\hline & LN_ROE & -12.079 & 68.512 & -.020 & -.176 & .861 \\
\hline & LN_CR & -85.389 & 76.284 & -.088 & -1.119 & .270 \\
\hline & DER & -298.575 & 122.351 & -.341 & -2.440 & .020 \\
\hline
\end{tabular}

Table 2. Results of Multiple Linear Regression Analysis

Table 2 shows that the Ln_EPS variable has sig. value of 0.000 that is lower than 0.05 . Therefore, it can be concluded that the Ln_EPS variable partially has positive and significant effects on stock prices. Tt does not support the hypothesis stating that the EPS partially and significantly has effects on the stock prices. This means that an increase in EPS contributes to the increase in stock prices, and the decline in EPS contributes to the decrease in stock prices.

The Ln_PER variable in Table 2 shows that the sig. value of 0.000 is lower than 0.05 . Therefore, it can be concluded that the Ln_PER variable partially has positive and significant effects on stock prices. It does not support the hypothesis stating that the PER partially and significantly has effects on stock prices. This means that higher PER increases price per share higher and lower PER decreases stock prices.

Table 2 shows that the Ln_PBV variable has a sig. value of 0.004 that is lower than 0.05 . Therefore, it can be concluded that the Ln_PBV variable partially has positive and significant effects on stock prices. Thus, it does not support the hypothesis stating that PBV partially and significantly has effects on stock prices. This means that higher PBV increases stock prices and the lower PBV decreases stock prices.

The Ln_ROE variable in table 2 has a sig. value of 0.861 that is higher than 0.05 . Therefore, it can be concluded that the Ln_ROE variable has no significant effect on the stock prices. Thus, it does not support the hypothesis stating that ROE partially and significantly has effects on stock prices. In other words, if there is an increase or a decrease in ROE, it does not affect stock prices. 
Table 2 shows that the $\mathrm{Ln}$ _CR variable has a sig. value of 0.270 that is higher than 0.05 . Therefore, it can be concluded that the Ln_CR variable has no significant effects on stock prices. Thus, it does not support the hypothesis stating that CR partially and significantly has effects on stock prices. Meaning to say, if there is an increase or a decrease in $C R$, it does not affect stock prices.

The DER variable in table 2 has a sig. value of 0.020 that is lower than 0.05 . Therefore, it can be concluded that the DER variable partially has negative and significant effects on stock prices. This means that the lower the percentage of DER, the stronger the company's ability to repay the debt, which subsequently increases stock prices.

Based on the results of the analysis in table 2 , it can be concluded that only 4 of 6 financial ratios that produce partial and significant effects on stock prices, i.e., EPS, PER, PBV and DER. Furthermore, these 4 ratios are employed to determine best performing shares in the companies in hospitality and tourism sub-sectors using Benjamin Graham's criteria.

Table 3. The Result of F Test

\begin{tabular}{crrrrrr}
\hline & Model & Sum of Squares & \multicolumn{1}{c}{ df } & Mean Square & F & Sig. \\
\hline 1 & Regression & 9099577.233 & 6 & 1516596.205 & 35.524 & $.000^{\mathrm{b}}$ \\
& Residual & 1536908.953 & 36 & 42691.915 & & \\
& Total & 10636486.186 & 42 & & & \\
\hline
\end{tabular}

a. Dependent Variable: $\mathrm{Pt}$

b. Predictors: (Constant), DER, LN_ROE, LN_CR, LN_PER, LN_PBV, LN_EPS

Table 3 shows that EPS, PER, PBV, ROE, CR and DER variables simultaneously produce sig. value of 0.000 that is lower than 0.05 . Therefore, it can be concluded that the 6 independent variables simultaneously have significant effects on stock prices. Thus, it does not support the hypothesis stating that the EPS, PER, PBV, ROE, $C R$ and DER simultaneously and significantly has effects on stock prices. This means that an increase in EPS, PER, PBV, ROE, CR and DER combined increase stock prices, and the decrease in EPS, PER, PBV, ROE, CR and DER combined decrease stock prices.

Performance Assessment of the Hospitality and Tourism Sub-sector using Benjamin Graham's Perspective
Earning per Share (EPS)

Table 4. EPS Calculation Result for 9 Companies (in \%)

\begin{tabular}{crrrrr}
\multicolumn{5}{c}{ Years 2012 - 2016 } \\
\hline \multirow{5}{*}{$\begin{array}{c}\text { Kode } \\
\text { Saham }\end{array}$} & 2012 & 2013 & 2014 & 2015 & 2016 \\
\cline { 2 - 6 } ARTA & 23,61 & 29,12 & 15,00 & 3,00 & 5,00 \\
BAYU & 47,30 & 109,24 & 109,24 & 79,57 & 77,18 \\
ICON & 1,27 & 1,27 & 1,14 & 0,23 & 2,62 \\
INPP & 1,85 & 4,08 & 11,22 & 8,96 & 15,21 \\
JIHD & 14,50 & 610,05 & 16,35 & 1,32 & 8,40 \\
JSPT & 75,17 & 70,47 & 110,40 & 76,16 & 53,74 \\
KPIG & 34,36 & 70,48 & 62,93 & 33,67 & 256,98 \\
PDES & 11,77 & 27,47 & 19,00 & 12,73 & 35,83 \\
SHID & 11,16 & 12,87 & 0,93 & 4,71 & 0,05 \\
\hline
\end{tabular}

Source: Processed Secondary Data (2018)

According to Graham (2017), well performing companies produce $>=30 \%$ EPS value for the last 5 years. Companies that meet these criteria are BAYU, JSPT and KPIG.

\section{Price to Earnings Ratio (PER)}

Table 5. PER Calculation Result for 9 Companies Years 2012-2016

\begin{tabular}{cccccc}
\hline \multirow{2}{*}{$\begin{array}{c}\text { Kode } \\
\text { Saham }\end{array}$} & 2012 & 2013 & 2014 & 2015 & 2016 \\
\cline { 2 - 6 } & \multicolumn{5}{c}{ Tahun } \\
ARTA & 13,3 & 7,0 & 22,2 & 127,0 & 56,0 \\
BAYU & 7,40 & 6,91 & 9,11 & 15,71 & 11,66 \\
ICON & 277,17 & 283,46 & 392,98 & 2630,43 & 190,84 \\
INPP & 351,02 & 221,88 & 18,36 & 39,96 & 37,15 \\
JIHD & 48,28 & 2,18 & 64,22 & 443,18 & 58,57 \\
JSPT & 9,98 & 10,64 & 6,82 & 12,30 & 47,41 \\
KPIG & 39,87 & 18,59 & 20,50 & 42,14 & 5,84 \\
PDES & 13,59 & 4,95 & 9,68 & 12,57 & 7,09 \\
SHID & 32,26 & 26,03 & 328,68 & 115,71 & 17.900 \\
\hline
\end{tabular}

Source: Processed Secondary Data (2018)

According to Graham (2017), a company is considered to be well performing if their PER value is $<15$, and the company that meets the criteria for 5 consecutive years is PDES.

\section{Price to Book Value (PBV)}

Table 6. PBV Calculation Result for 9 Companies Years 2012-2016 


\begin{tabular}{cccccc}
\hline \multirow{2}{*}{$\begin{array}{c}\text { Kode } \\
\text { Saham }\end{array}$} & \multicolumn{5}{c}{ Tahun } \\
\cline { 2 - 6 } & 2012 & 2013 & 2014 & 2015 & 2016 \\
\hline ARTA & 0,5 & 0,3 & 0,5 & 0,6 & 0,4 \\
BAYU & 0,75 & 0,64 & 1,19 & 1,18 & 0,85 \\
ICON & 11,45 & 11,68 & 3,27 & 4,21 & 3,43 \\
INPP & 0,86 & 0,52 & 0,42 & 0,63 & 1,55 \\
JIHD & 0,48 & 0,62 & 0,52 & 0,31 & 0,24 \\
JSPT & 0,96 & 0,85 & 0,75 & 0,88 & 2,24 \\
KPIG & 1,99 & 1,01 & 1,04 & 1,08 & 0,92 \\
PDES & 0,83 & 0,62 & 0,77 & 0,64 & 0,89 \\
SHID & 0,44 & 0,41 & 0,37 & 0,65 & 1,06 \\
\hline Source: Processed Secondary Data (2018)
\end{tabular}

According to Graham (2017), a company performs well if its' PBV is $\leq 1.5$. Five companies are found to have $\leq 1.5$ PBV for 5 consecutive years. They are ARTA, BAYU, JIHD, PDES and SHID.

\section{Debt to Equity Ratio (DER)}

Table 7. DER Calculation Result for 9 Companies Years 2012-2016

\begin{tabular}{cccccc}
\hline \multirow{2}{*}{$\begin{array}{c}\text { Kode } \\
\text { Saham }\end{array}$} & \multicolumn{5}{c}{ Tahun } \\
\cline { 2 - 6 } & 2012 & 2013 & 2014 & 2015 & 2016 \\
\hline ARTA & 0,323 & 0,235 & 0,199 & 0,199 & 0,199 \\
BAYU & 1,105 & 1,046 & 0,870 & 0,715 & 0,752 \\
ICON & 2,732 & 2,298 & 1,052 & 1,712 & 1,951 \\
INPP & 0,862 & 0,894 & 0,765 & 0,240 & 0,261 \\
JIHD & 0,319 & 0,285 & 0,386 & 0,454 & 0,382 \\
JSPT & 0,829 & 0,684 & 0,549 & 0,486 & 0,467 \\
KPIG & 0,234 & 0,207 & 0,243 & 0,254 & 0,257 \\
PDES & 0,672 & 0,870 & 0,964 & 1,209 & 1,275 \\
SHID & 0,414 & 0,597 & 0,542 & 0,545 & 0,525 \\
\hline
\end{tabular}

Source: Processed Secondary Data (2018)

According to Graham (2017), a company has a good performance if it has $\leq 1 \mathrm{D} / \mathrm{E}$ Ratio. Six companies are found to have $<1$ DER. They are ARTA, INPP, JIHD, JSPT, KPIG and SHID.

\section{Recommended stocks that are worth buying}

This research gives recommendation to potentials investors based on independent variables with significant effects on stock prices. These variables are EPS, PER and PBV. They partially produce positive effects on stock prices. Only DER produces negative effects on stock prices. Therefore, this research selects companies with good performance or having EPS $\geq 30 \%, \mathrm{PER}<15, \mathrm{PBV} \leq 1.5$ and $\mathrm{DER}<1$. The following are the names of companies that meet these four criteria for 5 consecutive years:

Table 8. Recommended stocks that are worth buying

\begin{tabular}{ccccc}
\hline \multirow{2}{*}{ No } & \multicolumn{4}{c}{ Kriteria } \\
\cline { 2 - 5 } & EPS $\geq 30 \%$ & PER $\leq 15 x$ & PBV $\leq 1.5$ & DER $\leq 1$ \\
\hline 1 & BAYU & PDES & ARTA & ARTA \\
2 & JSPT & & BAYU & INPP \\
3 & KPIG & & JIHD & JIHD \\
4 & & & PDES & JSPT \\
5 & & & SHID & KPIG \\
6 & & & & SHID \\
\hline
\end{tabular}

Table 8 shows the recommended stocks for purchasing with Benjamin Graham's criteria. Although for 5 consecutive years no company meets all four criteria, but there are seven companies that meets 2 of 4 specified criteria, namely ARTA (PT Artavest Tbk), BAYU (PT Bayu Buana Travel Service), JIHD (PT Jakarta Internasional Hotels and Development Tbk), JSPT (PT Setiabudi Internasional Tbk), KPIG (PT MNC Land Tbk), PDES (PT Destinasi Tirta Nusantara Tbk), and SHID (PT Hotel Sahid Jaya Internasional Tbk).

\section{CONCLUSION}

Variables of Earning Per Share (EPS), Price to Earnings Ratio (PER), Price to Book Value (PBV), Return on Equity (ROE), Current Ratio (CR), and Debt to Equity Ratio (DER) simultaneously affect stock prices of the companies in hospitality and tourism subsectors on Indonesia Stock Exchange.

Variables of Return on Equity (ROE) and Current Ratio (CR) produce no significant effects on stock prices of the companies in hospitality and tourism sub sectors on Indonesia Stock Exchange. This means that 
the two variables cannot be used as the basis of consideration in purchasing shares.

EPS, PER, PBV variables partially produce positive and significant effects on stock prices, while DER variable produces negative and significant effects on stock prices. This means that these four variables are illegible to be used as the basis of consideration in purchasing shares.

\section{RECOMENDATION}

Companies should maintain wellestablished financial ratios, e.g., DER remains $<1$, and EPS $>30 \%, \mathrm{PER}<15$ and $\mathrm{PBV}<1.5$.

Investors or potential investors in making decision in regards with buying or selling shares should take into consideration other factors that affect fluctuations in stock prices, such as internal political situation of a country, and external conditions, such as China-US trade war.

Researchers focusing on similar topic should increase the number of samples and prolong the observation period in the attempt to get better results.

\section{REFERENCES}

Artha, Danika R., Noer Azam A. dan Hendro S. 2014. Analisis Fundamental, Teknikal Dan Makroekonomi Harga Saham Sektor Pertanian. Jurnal Manajemen dan Kewirausahaan. Vol.16. No. 2. Hal. 1-16.

Asri, Muhammad Hamidun. 2017. Analisis Rasio Dengan Variabel EPS (Earning Per Share), ROA (Return On Assets), ROE (Return On Equity), BOPO (Biaya Operasional Pendapatan Operasional) Terhadap Harga Saham Perusahaan Perbankan. Jurnal Ekonomi Bisnis. Vol. 22 No.3. Hal. 275-287
Biro Perencanaan dan Keuangan Sekretariat Kementerian. 2016. Laporan Kinerja Kementrian Pariwisata. http://kemenpar.go.id/userfiles/ LAPORAN\%20KINERJA\%20KEMENPA R\%202016 FINAL.pdf. Diakses tanggal 3 Maret 2018.

Esmaeli, H. 2002. The Relationship Between Financial Ratios and Stock Prices of Listed Company in Tehran Stock Exchange. MS Thesis Accounting, Islamic Azad University, Science and Research Branch of Tehran.

Fitri, Sofi Alfia dan Yahya. 2016. Pengaruh Kinerja Keuangan Terhadap Harga Saham Perusahaan Food And Beverages Di BEI. Jurnal Ilmu dan Riset Manajemen. Vol. 5. No. 4. Hal 362-371.

Graham, Benjamin. 2017. The Intelligent Investor. Revised Edition. Harper Business Essentials. http://www.fxf1.com. Diakses tanggal 13 Juni 2018.

Hashemi, S. and F. Behzadfar. 2011. Journal of Financial Accounting. Pp 55-76.

https://id.tradingeconomics.com/unitedstates/gdp-growth, 2018

Javaid, Saima and Suha Alalawi. 2018. Performance and Profitability of Islamic Banks In Saudi Arabia : An Empirical Analysis. Asian Economic and Financial Review. Vol. 8, No. 1. Pp 3851.

Jefferson, Jere dan Naning Sudjatmoko. 2018. Shopping Saham Modal Sejuta Dari Nol Sampai Mahir. Jakarta: PT Elex Media Komputindo. 
Kohansal, M. R. , Amir D., Komeil M.K., and Abolfalz M. 2013. Relationship Between Financial Ratios and Stock Prices for the Food Industry Firms in Stock Exchange of Iran. World Applied Programming. Vol. 3. No. 10. Pp 512521.

Kurniawan, Andy. 2016. Analisis Hubungan Perubahan Price Earning Ratio (PER), Dividend Yield dan Harga Saham Pada Perusahaan Manufaktur Yang Listing Di BursaEfek Indonesia. Ekuivalensi Jurnal Ekonomi Bisnis. Vol. 2 No. 2 Oktober 2016. Hal 41-57.

Miri, SA and S. Ebrahimi. 2011. The Relationship Between Financial Ratios And Stock Price in The Metal Industry. Financial Accounting. Vo. 5 No.2. Pp 157-170.

Prasetyo, Gusniar Resty. 2014. Pengaruh Kinerja Keuangan Terhadap Harga Saham. Jurnal IImu \& Riset Akuntansi. Vol. 3 No. 4. Hal 1-14.

Said, Rasidah and Mohd Hanafi Tumin. 2011. Performance and Financial Ratios of Commercial Banks in Malaysia and China. International Review of Business Research Papers. Vol. 7, No. 2. Pp 157169.

Samsul, Mohamad. 2015. Pasar Modal dan Manajemen Portofolio. Edisi 2. Jakarta: Erlangga.

Santoso, Singgih. 2015. Menguasai Statistik Multivariat. Jakarta: PT Elex Media Komputindo.

Sari, Fransisca Indah P. dan Posma Sariguna J. Kennedy. 2017. Pengaruh Faktor Fundamental Terhadap Return Saham
Perusahaan Manufaktur Di BEI Periode 2009-2015.

Fundamental Management Journal. Volume 2 No.1 2017. Hal 87-97.

Setiawan, Sakina Rakhma Diah. 05 Februari 2018. "Ekonomi Indonesia 2017 Tumbuh 5,07 Persen, Tertinggi Sejak Tahun 2014", https://ekonomi.kompas.com/read/20 18/02/05/113820026/ekonomiindonesia-2017-tumbuh-507-persentertinggi-sejak-tahun-2014. Diakses tanggal 10 Maret 2018.

Subramanyam. 2014. Financial Statement Analysis $11^{\text {th }}$ edition. New York: Mc Graw Hill Education.

Sudana, I Made. 2015. Teori dan Praktik Manajemen Keuangan Perusahaan. Jakarta: Erlangga.

Tandelilin, Eduardus. 2017. Pasar Modal : Manajemen Portofolio \& Investasi. Yogyakarta: Kanisius. 